\title{
Austerity Cannot Explain the Current UK Economic Growth
}

\author{
Philip Arestis, University of Cambridge \\ Malcolm Sawyer, University of Leeds
}

\section{Introduction}

The purpose of this contribution is to explain the state of the current UK economic situation, without forgetting the prospects as highlighted by the published forecasts for the period to 2019 as explained below. It is claimed by government supporters that the current UK economic growth has emerged as a result of the austerity programme that the coalition government of the Conservative and Liberal Democrats parties in the UK has pursued since the general election of May 2010. The coalition government appears intent at continuing their austerity measures for the next five years to 2019, at least, and the Labour Party has joined in the clamour for continuing austerity. The incoming coalition government in May 2010 placed deficit reduction as central and played much more on doomsday scenarios of the reactions of credit ratings agencies and financial markets if actual and planned deficit reduction measures were not introduced.

The current UK economic growth has nothing to do with austerity causing it. It is largely due to the response of households to austerity in their attempt to maintain their level of consumption through borrowing, thereby increasing substantially private sector debt. What is also worrying is the failure of real wages to grow. Average wages grew by 1.25 per cent in 2013, below the consumer price inflation, clearly implying that they fell in real terms. Since then the annual rate of wage growth has fallen sharply. Households at the top of the distribution have been earning an increasing share of national income, while the rest have had to borrow more in order to be able to maintain their consumption needs. Both factors have enhanced household debt substantially as shown below. ${ }^{1}$

We proceed by looking at some well-known identities in section 2 to help us make the point, before we turn our attention to the current UK economic situation in section 3 . We summarise and conclude in section 4 .

\section{Macroeconomic Identities}

In what follows in this section we provide standard macroeconomic identities, which can be very useful for the analysis that follows. Two terms can be portrayed. One, where the identities can be viewed from their ex post aspect, in which case they can be described as simply income identities. Another, where the identities are in terms of their ex ante aspect, in

\footnotetext{
${ }^{1}$ It is interesting to note that household debt has not been dealt with in the same way as in the case of the relevant literature on the asset side of the household balance sheet (Zinman, 2014).
} 
which case they can be viewed as equilibrium conditions. Equation (1) below when approached from the latter point of view it would be equality between intended leakages and intended injections into the circular flow of income, and thereby suggesting an equilibrium situation.

So, in terms of the macro economy we have that total expenditure (E) is:

$\mathrm{E}=\mathrm{C}+\mathrm{I}+\mathrm{G}+\mathrm{X}-\mathrm{Q}+\mathrm{NI}$

where $\mathrm{C}$ is private consumption, $\mathrm{I}$ is private investment, $\mathrm{G}$ is government expenditure, $\mathrm{X}$ is exports of goods and services, $\mathrm{Q}$ is imports of goods and services, and $N I$ is net income from abroad.

We also have that national income $(\mathrm{Y})$ is:

$\mathrm{Y}=\mathrm{C}+\mathrm{S}+\mathrm{T}$

where $\mathrm{C}$ is as above, $S$ is private savings, and $T$ is tax revenues (net of transfers).

When $\mathrm{E}=\mathrm{Y}$, we have:

$\mathrm{C}+\mathrm{I}+\mathrm{G}+\mathrm{X}-\mathrm{Q}+\mathrm{NI}=\mathrm{C}+\mathrm{S}+\mathrm{T}$

Or,

$\mathrm{I}+\mathrm{G}+\mathrm{X}-\mathrm{Q}+\mathrm{NI}=\mathrm{S}+\mathrm{T}$

Or,

(1) $S+T+Q=I+G+X+N I$

(1) can be re-written as:

(2) $G-T=S-I+F A$

where $F A$ is financial account flows and it is equal to current account deficit $(=Q-X-N I)$.

A first implication, which emerges from equation (2), is that the discussion of budget deficits cannot proceed without consideration of private sector surpluses. With regard to issues of sustainability, a budget deficit is sustainable only if the private sector surplus is sustainable. A full consideration of that requires though some disaggregation of the private sector to 
consider the borrowing and lending within the private sector. For example, if there is a set of households who persistently run deficits, even though other sets of households persistently run surpluses, the position for the first set of households may be unsustainable. A relatively small budget deficit (and more so budget surplus) may be unsustainable because the deficits of components of the private sector may be unsustainable. An example of this could be the position in the UK circa 2007 when household savings were close to zero, and high consumer spending was underpinned by rising house prices; it is actually rather difficult to think that household savings close to zero and rising house prices (at 10 per cent plus) were sustainable. This is to suggest that the budget deficit position was not sustainable at the prevailing level, although it was too low, since the private sector position was itself not sustainable.

A second implication is that there can only be net private savings if there is a budget deficit or, in a similar manner, the point can be made by reference to the current account/financial account position. Thus when there is a tendency for propensity to save to exceed propensity to invest, a budget deficit becomes necessary to absorb the difference between intended savings and investment if savings and investment decisions are to be implemented.

\section{Current UK Economic Situation}

The UK Treasury claimed back in 2011 that austerity was "consistent with OECD and IMF research, which suggests that fiscal consolidation efforts that largely rely on spending restraint promote growth. Tax measures can be an effective tool for reducing the deficit quickly, allowing for phased reductions in public spending. The Government's consolidation plans therefore involve a rising contribution from public spending over the forecast period" (HM Treasury 2011, p. 15). ${ }^{2}$ It is then a matter of arithmetic that a reduction in the budget deficit has to be accompanied by some combination of reduction in private savings, rise in private investment and reduction in current account deficit (see equation 2). There are in effect two routes to a reduced budget deficit: cuts in public expenditure and raises in taxes, both of which depress economic activity such that the right-hand side of the above equation falls (e.g. savings fall, current account deficit declines); or there is a pick-up in investment and exports, which enables the deficit to fall alongside an expansion in economic activity. The view underlying government policy appears to have been that an expansion of investment and exports would come as a result of deficit reductions. Table 1 shows what has happened since 2010 and we discuss this experience in what follows in the rest of this

\footnotetext{
${ }^{2}$ It should be noted, though, that the IMF has actually changed its mind since the relevant publication referred to in the text. In the October 2014 Economic Outlook publication (IMF, 2014) it is argued that substantially increased public infrastructure investment can significantly boost growth. Indeed it is suggested that the stimulative effect is stronger when investment is financed through borrowing rather than reducing other spending or raising taxes. It is also argued that properly designed infrastructure investment would reduce government debt.
} 
section. We also account for the projections of the Office for Budget Responsibility (OBR) ${ }^{3}$ and other relevant publications such as OECD and IMF ones, as stated in Table 1.

The UK economy has been expanding recently since 2013 (see Table 1 for the relevant figures referred to in this contribution). The government budget deficit has been decreasing, although not as fast as planned in 2010, ${ }^{4}$ inflation has been around the official target of 2 per cent and the unemployment rate is expected to fall near below 6 per cent by the end of 2014 (the latest actual figures for 2014 show that the UK unemployment rate was 6.0 in period June to August 2014, from the peak of 8.1 percent in 2011). Unemployment has been falling but real wages have also continued to fall. The Office of National Statistics (ONS) reports earnings rising by under 1 per cent (to October 2014) well below the rate of inflation. The restrictive fiscal-policy stance has exerted a negative influence on aggregate demand and growth, which has been offset by rising domestic private demand. The current account deficit deteriorated in the past years, though it is forecast to improve from 2014 onwards, which repeats the type of forecasts which have frequently been made that the current account deficit will improve in the future. Net exports have had a negligible effect on output growth - even a negative impact is noted. On the contrary over the period 2012-2013 the current account deficit increased by roughly 1.2 percent. It is also the case that sluggish investment has been as much part of the story as the current account deficit. ${ }^{5}$ In terms of monetary policy, the 'forward guidance' of the Bank of England, such as it is, ${ }^{6}$ indicates that the rate of interest

${ }^{3}$ The OBR was established in 2010 to provide independent and authoritative analysis of the UK's public finances.

${ }^{4}$ The UK Chancellor of the Exchequer promised at the time of his appointment in 2010 to reduce the deficit significantly and completely within five years. It is only two-fifths of achieving it in September 2014 (The Economist, 2014, p. 31).

${ }^{5}$ The ONS in its Statistical Bulletin (30 September, 2014) provides revised national accounts data, which suggests that UK's GDP growth rate in the second quarter of 2014 was 2.7 per cent larger than its pre-crisis peak (first quarter of 2008), and that it was 0.9 per cent higher between April and July 2014; however it slowed to 0.7 per cent in the third quarter of 2014. Also the household savings ratio in the second quarter of 2014 was 6.7 per cent, slightly above the 5.7 per cent of the first quarter of 2014 with gross fixed capital formation rising to 1.3 per cent in the second quarter of 2014, significantly smaller than the nearly 6 percent of the third quarter of 2010. Exports contracted to a greater extent than imports in the second quarter of 2014, with the net trade balance worsening in relation to the second quarter of 2013, due to the strong currency. Business activity in the services sector expanded at a slower pace by September 2014, a sign that the UK economy is losing some of its pace. This is due to a slowdown in manufacturing activity and output (which is still 4.4 per cent lower than its pre-crisis peak) in view of weak demand in the euro area for UK products (it is also the case that growth in the UK service sector slowed to a three-month low in September 2014, the result of slow wage growth with pay lagging behind inflation). It should be noted, though, that higher growth has not been accompanied with the expected higher tax receipts. Real household disposable income per head has been revised downwards to 2.7 per cent below the 2008 peak as opposed to 1.8 per cent of previous estimations. These revisions can be partly explained by the move from the 1995 European System of Accounts to the 2010 European System of Accounts (which includes additional areas of the economy than previously). It should also be noted that "Estimates for the most recent quarters are provisional and are subject to revision in the light of updated source information" (ONS Bulletin, 30 September 2014).

${ }^{6}$ The new governor of the Bank of England a month after he had taken office on the $1^{\text {st }}$ of July 2013, promoted the idea of 'forward guidance', namely a pledge that no immediate plans were in place to raise interest rates at least before unemployment fell below 7 percent. However, by the end of 2013 it became obvious that unemployment would reach 7 percent by the beginning of 2014. In February 2014 'forward guidance' was 
under the control of the central bank and the 'Quantitative Easing' type of policy would remain as they are for the near future. ${ }^{7}$

The OBR is projecting a further decrease in the budget deficit in the next three years and stabilising thereafter (see Table 1). At the same time acceleration in the rate of growth is projected, which would keep unemployment on a downward trend. The IMF's position on the current UK economy has been reported (Financial Times, 7 June 2014) at its recent visit to London to conduct its annual economic inspection. The IMF welcomed the 'great economic performance' of the UK but suggested that rapidly rising house prices, weak productivity growth and trade deficit are the three principal risks to the recovery's sustainability. The Bank of England (see Barrett et al., 2014) reports that UK productivity is 16 percent below its pre-crisis trend, and admits that there is still a significant degree of uncertainty in terms of the causes of such decline.

Consumer spending growth in 2013 appears to have been financed more by lower saving than by higher incomes. ${ }^{8}$ With consumer spending growth forecast to outpace disposable income growth over the near term, it is expected that the saving ratio will fall from just under 5 per cent in 2013 to just over 4 per cent in 2014, before declining gradually to around 3 per cent by the end of the forecast period. With sluggish net export demand, economic growth becomes dependent on rising private borrowing with the private sector continuing to spend in excess of its income (Papadimitriou et al., 2014, p. 2). We suggest that this is true for the UK since 2010 when austerity policies were adopted and introduced. The UK actually suffered badly during the financial crisis that emerged in August 2007. ${ }^{9}$ Real GDP fell by 7 percent from peak to trough, considerably more than in the US. Unemployment rose by 3 percentage points, and two of the biggest UK banks desperately needed a 'bail out', which was provided.

It is the case, and as Table 1 shows, exports have had no effect on the recovery since 2010 and the government deficit is declining. The government deficit as a percentage of GDP is actually projected to decrease from 5.9 percent in 2013 to 5.3 percent in 2014, though recent deficit data cast some doubt on that figure and then fall further to reach a low 0.2 percent by 2019. At the same time, GDP growth is projected to increase by 3.2 percent in 2014, by 2.7

replaced by a range of indicators to assess the spare capacity in the economy rather than focusing on unemployment in terms of deciding to increase the rate of interest.

${ }^{7}$ The Bank of England rate of interest is 0.5 percent and the QE amounts to $£ 375$ billion.

${ }^{8}$ The ONS provides data that shows households saved $4.2 \%$ of their income in the first quarter of 2013 . This is below the $7.4 \%$ level of the year before, and it is indeed the lowest in four years.

\footnotetext{
${ }^{9}$ Interestingly enough, a recent Bank of England contribution (Bunn and Rostom, 2014) argues that household borrowing produced problems in view of its build up of debt prior to the August 2007 financial crisis, which is blamed for the depth of the 'great recession'. A great deal of the drop in consumption between 2007 and 2009 is attributed to 'debt-tightening' by indebted households. It also recognises that clamping down on household borrowing might limit growth in the upswing. It is suggested that this "was a key reason why the Financial Policy Committee (FPC) took policy actions in June 2014 to insure against the risks from a further significant increase in the number of highly indebted households" (p. 305).
} 
percent in 2015, and by 2.6 in 2016 and 2017, and then to 2.5 percent in 2018 and by 2019 to 2.4 percent. $^{10}$ The unemployment rate is projected to fall to 5.5 percent by 2018 and 5.4 percent 2019, while the inflation rate is expected to be around the target of the Bank of England (this being 2 percent with 1 percentage point 'tolerance level' either side of the target inflation rate). The current account deficit as a percentage of GDP is not expected to change by much either after 2015 as Table 1 shows.

We may note at this point that, and as Eggertson and Krugman (2012) hypothesise, there is a limit on how far increases in household debt can go, and if that limit is revised downwards indebted households would reduce their spending sharply and significantly with no effective response on the part of non-debtors. It is also important to note that post-2008 consumer spending in the UK has been affected by household debt. Bunn and Rustom (2014) make the point when they argue that "Further advances on mortgages (additional borrowing secured against a house but not used to buy the property) and unsecured lending (such as personal loans or credit card debt) are forms of borrowing that are more likely to be used to finance consumption than new mortgage lending. Over the past fifteen years consumption has shown some correlation with further advances, although the relationship with unsecured lending is less clear" (p. 307). Evidence is provided by Bunn and Rustom (op. cit.) that clearly suggests that "a key is that UK households with high levels of mortgage debt made larger adjustments in spending after 2007" (p. 307); and that "There is evidence that households with high levels of debt have provided some support to UK consumption and GDP during periods of economic growth, but have also contributed to deeper downturns and more protracted recoveries, especially in the wake of the Great Recession" (pp. 313-314). Also, Boyce (2011) suggests that "One in four people in Britain are using over 40 per cent of their wages each month just to pay off non-mortgage debt, according to new data".

Households, when experiencing stagnating incomes to that extent, they expand their debt in order to finance their consumption expenditure which amount to around two-thirds of demand); and the UK households over the period of examination have been undertaking just that. Under such circumstances, the recovery, such as it is, relies on private-sector borrowing. Outstanding household debt in the UK was 72.0 percent of GDP over the period 1998 to 2002 (in 1960 it amounted to less than 15 percent of GDP); between 2003 and 2007 it shot to 94.3 percent of GDP, and it has been increasing since (Arestis and Karakitsos, 2013). Bunn and Rostom (2014) state that "the household debt to income ratio rose from around $100 \%$ in 1999 to a peak of $160 \%$ in 2008 " (p. 305). The household debt to GDP ratio fell over the period 2008 to 2013 by over 20 percentage points. The "cuts in spending associated with debt are estimated to have reduced aggregate private consumption by around 2\% after 2007" (Bunn and Rostrom, 2014, p. 304). However, looking forward, according to the OBR's economic

\footnotetext{
${ }^{10}$ NIESR (2014) reports that, as of May 2014, UK output was 0.2 per cent higher than its previous peak of over six years ago (January 2008). However, GDP per head and real wages are still below the pre-crisis levels. Interestingly enough, though, the OBR (2014a) estimations suggest that real incomes will not return to their previous peak levels of 2009 until 2018 at the earliest.
} 
forecast (OBR, 2014b), released alongside the OBR (2014a), the total household liability is set to increase by a far greater amount between 2014 and 2019. OBR expects UK households to be in $£ 2.251$ trillion of debt by 2019 , an increase of a staggering 43 percent. This is all confirmed by Table 1 (Household Sectoral Balances as percentage of GDP). Household sectoral balances as percentage of GDP have been falling since 2010/2011 significantly and turning into negative from 2014/2015 onwards, expected to reach -3.9 percent by 2019/2020. This is clearly a state of concern; and as the Bank of England (2013) concludes “... high levels of debt remain a source of vulnerability. For example, highly indebted borrowers would be less able to withstand a fall in their incomes or an increase in their borrowing costs" (pp. 16-17).

These figures for the household debt are not surprising since the simple accounting identities reported in section 2 clearly indicate that current account deficits should be mirrored by domestic deficits, both public and private. The continuous accumulation of these domestic deficits becomes an unsustainable process that leads eventually to a crisis. Fiscal austerity makes matters worse since the 'burden' of borrowing falls on the private sector, which is much more vulnerable in terms of the accumulation of liabilities. It was precisely this process of high private expenditure through borrowing that led to the 'great recession' (see Arestis and Karakitsos, 2013); and as Stiglitz (2014) argues, recovery of the economy through consumption is worrying for "It means return to unsustainable patterns of the kind marked the pre-crisis days" (p. 20).

In order for the projections reported in Table 1 for the years 2014 to 2019 to materialise net private sector lending, that is S-I, will have to fall and converge to zero by the end of 2019. ${ }^{11}$ For otherwise, and as Godley (1999) suggested some time ago in the case of the US economy and the World, and it is still very valid for the UK economy, "if spending were to stop rising relative to income without there being either a fiscal relaxation or a sharp recovery in net exports, the impetus that has driven the expansion so far would evaporate and output would not grow fast enough to stop unemployment from rising. If, as seems likely, private expenditure at some stage reverts to its normal relationship with income, there will be, given present [restrictive] fiscal plans, a severe and unusually protracted recession with a large rise in unemployment" (p. 3).

\footnotetext{
${ }^{11}$ The UK Financial Policy Committee (FPC) of the Bank of England initiated on the $26^{\text {th }}$ of June 2014 new macroprudential policies aiming at containing housing price increases through its regulation of lending - a move designed to bear down on the risks of excessive debt according to the Bank of England (see PRA, 2014, for full details). Mortgage lenders will go through a new test of affordability, which would enable them to establish whether new borrowers could still afford to repay their mortgages if within five years interest rates were three percentage points higher than they were at the time of the loan. Also a cap of 15 percent in terms of the proportion of mortgages that can cover more than 4.5 times the borrowers' income. About only 10 percent of existing mortgage loans are at 4.5 percent times income when the new macroprudential measures were introduced, which implies that banks could expand lending further. It should be noted that re-mortgaging is excluded from this rule. These credit-control measures, however, are not 'a stringent cap', and as such their impact should be minimal, according to the Bank of England.
} 


\section{Summary and Conclusions}

UK's current recovery seems to be strong but fragile and cause for concern. It is thought by the austerity proponents as the right model for recovery. We have argued, however, that the current recovery has come about in view of the household sector undertaking increasingly more debt to satisfy their consumption needs. The new deputy governor of the Bank of England at her first Treasury Select Committee hearing (9 July 2014) made the point that a spiralling level of household debt at the back of rising house prices is the biggest thread to the UK economic recovery. Also, as Stiglitz (2014) argues, recovery of the economy through consumption is worrying for "It means return to unsustainable patterns of the kind marked the pre-crisis days" (p. 20). A further concern is the balance of payments, which despite the 25 percent real depreciation of sterling in 2007-08 the current account deteriorated by 2012-13 significantly, and expected to continue in deficit (see Table 1). But even with the promising expected growth rate of 3.2 per cent in 2014 the rest of the path of growth and the subsequent expected growth rates, as shown in Table 1, are well below the trajectory followed prior to the great recession. The increasing accumulation of household debt certainly helped to stimulate growth but cannot continue ad infinitum. It is also the case that real earnings in the UK are still falling, and household debt is still well above its long-term average. The falling savings rate has certainly helped to finance higher spending but it cannot go on falling indefinitely.

Still, UK's households remain far too indebted; and there is the real danger when interest rates start to rise again for it would have serious implications. And as the Bank of England (2014) suggests "At higher levels of indebtedness, households are more likely to encounter payment difficulties in the face of shocks to income and interest rates. This could pose direct risks to the resilience of the UK banking system, and indirect risks via its impact on economic stability" (p. 52). Indeed, and as a report by the Resolution Foundation (Blacklock and Whittaker, 2014) suggests, given the high household debt in the UK a rise in the rate of interest by the Bank of England's monetary policy committee would have serious effects. As the report puts it: "even a relatively benign unwinding of today's emergency interest rate position allied with anticipated growth in household incomes has the potential to roughly double the number of households facing some form of repayment problem by $2018^{\prime \prime}$ (p. 5). ${ }^{12}$ If anything a crisis may be on the horizon.

\footnotetext{
${ }^{12}$ This is supported by the conclusions of another report, the $16^{\text {th }}$ Geneva Report, "Deleveraging? What Deleveraging? The 16th Geneva Report on the World Economy", commissioned by the International Centre for Monetary and Banking Studies (as reported in the Financial Times, 29 September, 2014). It is suggested in the report that world debt (in both developed and emerging countries) has risen from 160 per cent of GDP in 2001 to 215 per cent in 2013. The report concludes that authorities around the world should limit borrowing.
} 
We conclude by suggesting that the UK experience fits closely with the view that budget deficits have an endogenous character, and that fiscal consolidation does not in itself stimulate investment and exports. It is the case, and as we have demonstrated, that the main condition for deficit reduction is the stimulation of private demand in the form of investment and exports:- - The UK Chancellor of the Exchequer, George Osborn, in his Autumn Budget Statement on the $3^{\text {rd }}$ of December 2014, "was forced to admit that the underlying state of the public finances was in a worse state than expected" and as a result "austerity would have to be extended and Britain's economic hard times would continue longer than thought" (Financial Times, 4 December, 2014). The failure of the Coalition government to eliminate the budget deficit as it had aimed to do can be ascribed to a short-fall in tax revenue rather than a failure to reduce public expenditure; and the short-fall of tax revenue to a failure of exports and investment to recover. Piling on more austerity will have a similar failure of the budget to come into balance unless there is a major recovery of investment and net exports.

TABLE 1: UK Relevant Data: Actual (2010 to 2013) and Forecast (2014 to 2019)

\begin{tabular}{|c|c|c|c|c|c|c|c|c|c|c|}
\hline & 2010 & 2011 & 2012 & 2013 & 2014 & 2015 & 2016 & 2017 & 2018 & 2019 \\
\hline $\begin{array}{l}\text { Real GDP } \\
\text { Growth } \\
\text { (Percentage } \\
\text { Change) }\end{array}$ & 1.7 & 1.1 & 0.3 & 1.7 & 3.2 & 2.7 & 2.6 & 2.6 & 2.5 & 2.4 \\
\hline $\begin{array}{l}\text { Government } \\
\text { Deficit (Percent } \\
\text { of GDP) }\end{array}$ & -10.0 & -7.9 & -6.3 & -5.9 & -5.3 & -4.1 & -2.4 & -0.8 & -0.2 & -0.2 \\
\hline $\begin{array}{l}\text { Unemployment } \\
\text { Rate }\end{array}$ & 7.9 & 8.1 & 7.9 & 7.6 & 6.8 & 6.5 & 6.1 & 5.7 & 5.5 & 5.4 \\
\hline $\begin{array}{l}\text { Inflation Rate } \\
\text { (Harmonised } \\
\text { Index of } \\
\text { Consumer Prices) }\end{array}$ & 3.3 & 4.5 & 2.8 & 2.6 & 1.9 & 2.0 & 2.0 & 2.0 & 2.1 & 2.0 \\
\hline $\begin{array}{l}\text { Current Account } \\
\text { Deficit (Percent } \\
\text { of GDP) }\end{array}$ & -2.7 & -1.5 & -3.7 & -3.6 & -2.3 & -1.9 & -1.7 & -1.5 & -1.5 & -1.4 \\
\hline $\begin{array}{l}\text { Household } \\
\text { Sectoral Balances } \\
\text { (Percent of GDP) }\end{array}$ & 2.8 & 1.1 & 1.2 & 0.7 & -0.5 & -1.1 & -1.9 & -2.8 & -3.4 & -3.9 \\
\hline
\end{tabular}

Source: OECD, Economic Outlook, Statistical Annex (May, 2014) and IMF Economic Outlook (April, 2014). Projections for 2014-2019 are from the IMF Economic Outlook (April, 2014) and OBR (April, 2014). 
Note: The sectoral balances for the household sector refer to the relevant financial year.

\section{References}

Formatted: Line spacing: single

Arestis, P. and Karakitsos, E. (2013), Financial Stability in the Aftermath of the 'Great Recession', Houndmills, Basingstoke: Palgrave Macmillan.

Bank of England (2013), "Short-term Risks to Financial Stability", Financial Stability Report, 28 November 2013.2 Available http://www.bankofengland.co.uk/publications/Documents/fsr/2013/fsr34sec2.pdf

Bank of England (2014), "Prospects for Financial Stability", Financial Stability Report, 35 June $2014 . \quad$ Available $\quad$ at: http://www.bankofengland.co.uk/publications/Documents/fsr/2014/fsr35sec5.pdf

Barnett, A., Batten, S., Chin, A., Franklin, J. and Sebastió-Barriel, M. (2014), "The UK Productivity Puzzle", Bank of England Quarterly Bulletin, 54(2), pp. 114-128.

Blacklock, K. and Whittaker, M. (2014), "Hangover Cure: Dealing with the Household Overhang as Interest Rates Rise", Resolution Foundation Report, July. Available at: http://www.resolutionfoundation.org/wp-content/uploads/2014/07/Hangover-cure-dealingwith-the-household-debt-overhang-as-interest-rates-rise.pdf

Boyce, L. (2011), "One in Four Spend Almost Half their Income to Repay Non-Mortgage Debt". Available at: http://www.thisismoney.co.uk/money/bills/article-2039666/One-spendhalf-income-repay-non-mortgage-debt.html\#ixzz3ESch24Vr

Bunn, P. and Rostom, M. (2014), "Household Debt and Spending", Bank of England Quarterly Bulletin, 54 (3), pp. 304-315.

Eggertson, G. and Krugman, P. (2012), "Debt Delevaraging and the Liquidity Trap: A FisherMinsky-Koo Approach”, Quarterly Journal of Economics, 127(3), 1469-1513.
Formatted: Font: (Default) Times New Roman

Formatted: Font: (Default) Times New Roman

Formatted: Font: (Default) Times New Roman

Formatted: Font: (Default) Times New Roman

Formatted: Font: (Default) Times New Roman

Formatted: Font: (Default) Times New Roman

Formatted: Font: (Default) Times New Roman 
| Godley, W. (1999), "Seven Unsustainable Processes: Medium-Term Prospects and Policies for the United States and the World", Strategic Analysis, Annandale-on-Hudson, NY: Levy Economics Institute of Bard College, January.

National Institute of Economic and Social Research (NIESR) (2014), June 2014 GDP Estimates". Available at:

http://niesr.ac.uk/publications/june-2014-gdp-estimates\#.U5iHPygb-rg

Office for Budget Responsibility (OBR) (2014a), "Economic and Fiscal Outlook”, Presented to Parliament by the Economic Secretary to the Treasury by Command of Her Majesty, March.

Office for Budget Responsibility (OBR) (2014b), "Commentary on the Public Sector Finances, Release March 2014", 23 April.

HM Treasury (2011), Budget 2011, London: The Stationery Office, HC836.

International Monetary Fund (IMF) (2014), World Economic Outlook, October 2014, Washington D.C.: International Monetary Fund. Available at: http://www.imf.org/external/pubs/ft/weo/2014/02/pdf/text.pdf

Papadimitriou, D.B., Nikiforos, M., Zezza, G. and Hannsgen, G. (2014), "Is Rising Inequality a Hindrance to the US Economic Recovery?", Strategic Analysis, Annandale-on-Hudson, NY: Levy Economics Institute of Bard College, April.

Prudential Regulation Authority (PRA) (2014), "Implementing the Financial Policy Committee's Recommendation on Loan to Income Ratios in Mortgage Lending", Consultation Paper CP11/14, June.

Stiglitz, J.E. (2014), "Reconstructing Macroeconomic Theory to Manage Economic Policy", NBER Working Paper No. 20517, September, Washington D.C.: National Bureau of Economics Research. Available at: http://www.nber.org/papers/w20517.pdf

The Economist (2014), “The Tax-Free Recover”, 20 September.

Zinman, J. (2014), "Household Debt: Facts, Puzzles, Theories, and Policies", NBER Working Paper No. 20496, September, Washington D.C.: National Bureau of Economics Research. Available at: http://www.nber.org/papers/w20496 